\title{
DIGITAL IMAGE CORRELATION IN ANALYSIS OF STIFFNESS IN LOCAL ZONES OF WELDED JOINTS
}

\author{
Milos Milosevic, Nenad Milosevic, Simon Sedmak, Uros Tatic, Nenad Mitrovic, Sergej Hloch, \\ Radomir Jovicic
}

Original scientific paper The behaviour of welded joints in local zones, as well as their mutual influence, represents one of the main challenges in welded structure design. Namely, the main issue lies in determining the mechanical properties of materials in a welded joint. These properties are necessary for an accurate calculation of welded structure integrity. The possibility of obtaining local strain/displacement values makes the "Digital Image Correlation" (DIC) technique suitable for welded joint testing and determining of mechanical properties. In this paper a tensile testing machine was used for loading and a two camera system was used for 3D strain analysis. A specimen with parallel sides, obtained by welding of a $\mathrm{V}$ joint was used. Calibration was performed prior to testing, in order to ensure dimensional consistency of the system. Application of DIC technique using Aramis software for measuring local displacement/strain in a welded joint is presented in this paper. Due to tension in the V-weld specimen (Base material - S235JRG2, electrode wire - VAC 60), mutual influence of mechanical properties of local zones is present, wherein the root weld had the highest stiffness.

Keywords: Aramis software; Digital Image Correlation; strain analysis; stiffness; welded joints

\section{Korelacija digitalne slike pri analizi krutosti u lokalnim zonama zavarenih spojeva}

Izvorni znanstveni članak

Ponašanje zavarenih spojeva u lokalnim zonama, kao i njihov uzajamni utjecaj, jedan je od glavnih problema u projektu zavarene konstrukcije. Naime, osnovni je problem u određivanju mehaničkih svojstava materijala u zavarenom spoju. Ta su svojstva neophodna za točan proračun zavarenih konstrukcija. Mogućnost dobivanja vrijednosti lokalne deformacije/pomaka čini tehniku "Digital Image Correlation" (DIC) pogodnom za ispitivanje zavarenog spoja i određivanje mehaničkih svojstava. Tijekom ovih ispitivanja za opterećenje je korišten uređaj za vlačnu provjeru, a dvije kamere su korištene za 3D analizu deformacije. Upotrijebljen je uzorak s paralelnim stranama dobiven zavarivanjem V spoja. Prije ispitivanja izvršeno je kalibriranje kako bi se dobili što točniji rezultati. U radu je predstavljena primjena DIC tehnike korištenjem Aramis softvera za mjerenje lokalnog pomaka/deformacije u zavarenom spoju. Dobiveni rezultati pokazuju da je zavareni spoj bio nejednako deformiran s prednje i zadnje strane korijena, u području elastične deformacije, tijekom vlačnog opterećenja. Zbog vlaka u uzorku s V-zavarom (osnovni materijal S235JRG2, žica elektrode - VAC 60), postoji uzajamni utjecaj mehaničkih svojstava lokalnih zona, gdje je krutost korijena zavara najviša.

Ključne riječi: analiza deformacije; Aramis softver; korelacija digitalne slike; krutost; zavareni spojevi

\section{Introduction}

In engineering practice, strain measuring can be performed in various ways. In general, strain measuring techniques can be divided into: contact measuring, i.e. direct measuring (using extensometers, strain gauges...) and non-contact measuring (lasers, cameras, and stereography), $[1 \div 11]$. Non-contact methods have been rapidly developed in recent decades and there are currently a large number of these methods. Some of them include techniques such as "Digital Image Correlation" (DIC), interferometry, stereography, etc. Non-contact testing is suitable for both standard applications, like calculation of stresses, and non-standard cases, such as measuring and analysis during non-destructive testing (NDT), [12 $\div 14]$. Strains and displacements on surface discontinuities or near them can be detected by measuring the object before, during and after loading. The load can be applied in several ways, for example by heating, due to chemical reactions, or as static and dynamic load. Strain measuring of welded joints is complex due to the structure of the weld, which can be observed as a combination of three zones with different properties base metal (BM), heat affected zone (HAZ) and weld metal (WM) [14:18].

Local properties in different zones of a welded joint can be determined by making micro-specimens and subjecting them to standard testing methods. However, this excludes the mutual influence of different welded joint zones during the loading $[19 \div 22]$. In a paper by
Jovicic et al. [3], the complete strain field of a welded joint specimen was analysed immediately before fracture, without taking into consideration the effects of load and the local zone on the slope of the stress-strain curve. Stress-strain curve slope in the local zone represents its stiffness. During the making of welded joints and heat input, changes occur in the crystal structure of the base material, which results in changes in stiffness of the newly formed local zones.

Digital Image Correlation is a technique for obtaining numerous data about the deformation of the tested specimen. Measuring is based on comparing series of consecutive images obtained in a specific time interval during testing. Depending on the testing requirements, DIC method can be applied as 2D, using a single camera, or as $3 \mathrm{D}$, using two cameras [12, $22 \div 24]$.

Major advantages of DIC are:

- It is a non-contact technique, making it capable of testing large structures, as well as structures with complex geometry.

- High accuracy, thanks to a type of calibration used in this method, which is adjusted according to the measuring volume.

- $\quad$ Post-processing enables different types of results for a single experiment.

The aim of this paper was to determine the mutual influence of local zones in a welded joint by defining their stiffness, using non-contact DIC method.

For this purpose, the following hypothesis was made: 
- Due to tension in a V-weld specimen (Base material S235JRG2, electrode wire - VAC 60), mutual influence of mechanical properties of local zones is present, wherein the root weld has the highest stiffness.

\section{Material and testing procedure}

The specimen was made from plates welded using Gas Metal Arc Welding process with $\mathrm{CO}_{2}$ as the shield gas. Base metal was S235JRG2, whereas electrode wire VAC 60 (Elektrode Jesenice) was used as the filler metal.

Table 1 shows the mechanical properties of the base metal, indicating low-alloyed steel with good weldability, which does not require pre-heating or additional heat treatment. Specimen dimensions were $182 \times 20,2 \times 9,2$ $\mathrm{mm}$, as shown in Fig. 1. Determining of its mechanical properties was performed obtaining real stress-strain values in zones of interest. From the diagram of real stress-strain, a straight line is obtained using linear approximation in elastic region. The slope of this line represents the stiffness of the defined zones in the welded joint (BM, HAZ, WM).

Table 1 Mechanical properties of the base material

\begin{tabular}{|c|c|}
\hline Nominal thickness $(\mathrm{mm})$ & up to $100 \mathrm{~mm}$ \\
\hline$R_{\mathrm{e}}(\mathrm{MPa})$ & 215 \\
\hline$R_{\mathrm{m}}(\mathrm{MPa})$ & 340 \\
\hline A-longitudinal $\%$ & 24 \\
\hline A-transverse $\%$ & 17 \\
\hline
\end{tabular}

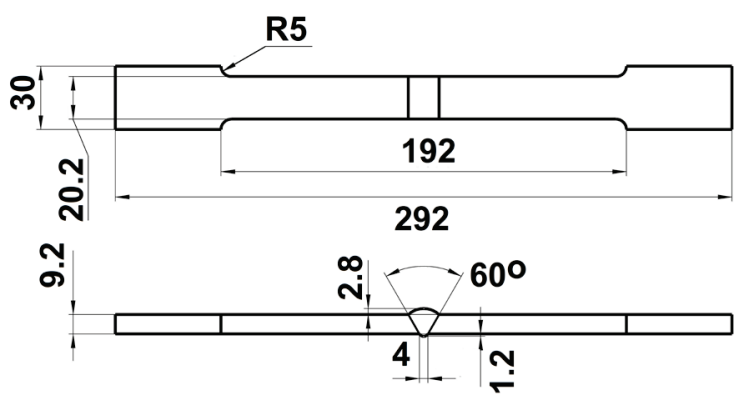

Figure 1 Dimension of the specimen used (mm)

Experiment was conducted using 3D system Aramis $2 \mathrm{M}$ (GOM, Braunschweig, Germany) and Universal Testing Machine (Instron, USA). In accordance with specimen dimensions, the measuring volume of $100 \times 100$ $\times 75 \mathrm{~mm}$ was defined, and based on it, a calibration panel CP20 $90 \times 72$ was selected. Calibration was performed in thirteen steps, by moving the calibration panel in order to obtain dimensional consistency of the system. Calibration deviation was 0,038 pixels. Prior to recording, a layer of white paint was applied to the measuring surface, followed by a layer of finely dispersed black points (Kenda Color Acril- 207ico, Kenda Farben).

Fig. 2 shows the experiment setup, indicating the jaws of tensile test machine (No. 1), cameras (No. 2), the specimen (No. 3) and the lamp (No. 4). The lamp is used as a source of constant light in order to avoid the influence of variable outside lighting.

Fig. 3 shows the positions of measuring lines. Dotted lines visible in Fig. 3 are sections 1 and 2 and represent fusion lines and denote the border between WM and HAZ areas. Measuring lines 2, 3, 5 and 6 were placed $2 \div 3 \mathrm{~mm}$ away from the HAZ, in the WM. Line 1 is located at the root of the WM, whereas line 4 is located in the same plane as lines 2 and 3 but in the WM front zone.
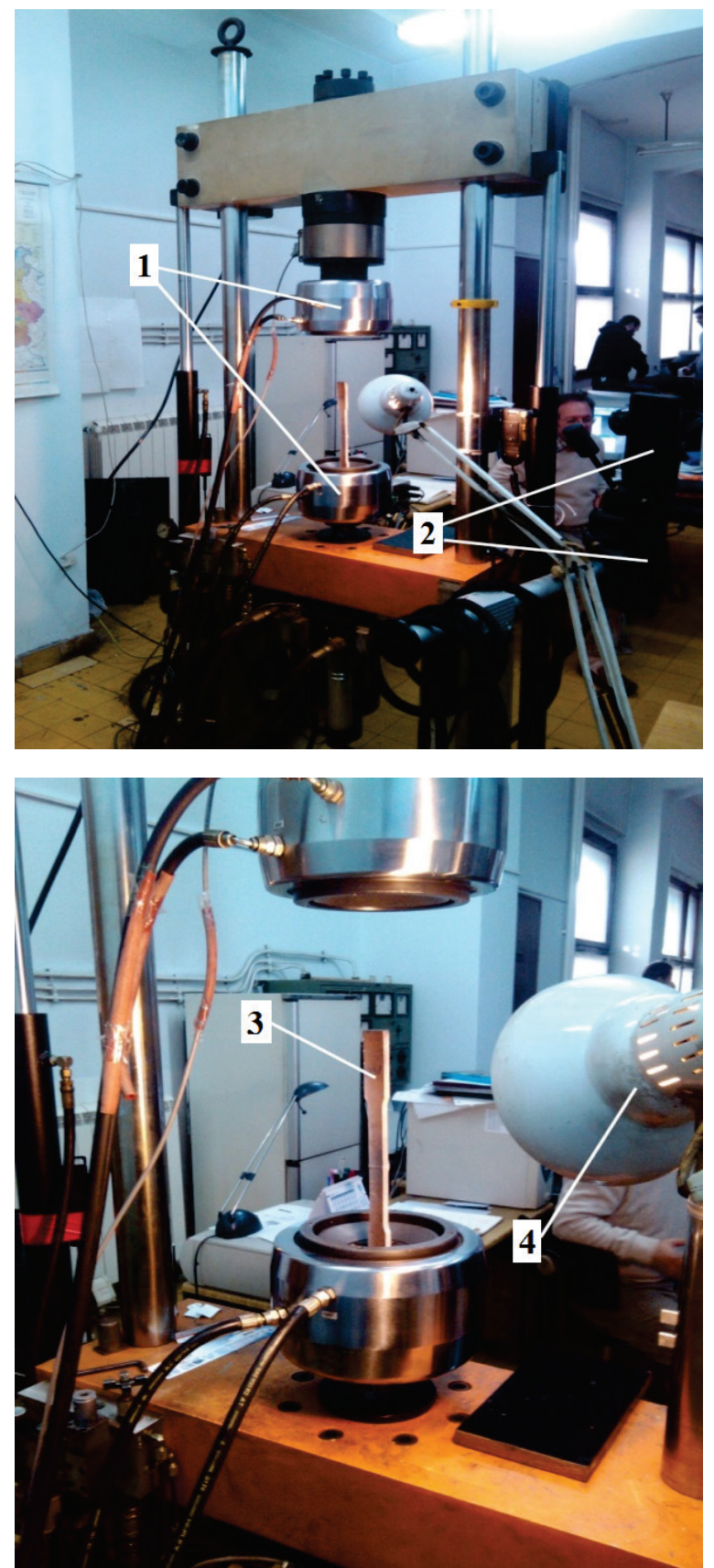

Figure 2 Experiment setup

Strain was obtained by using a tool called "pointpoint" distance, which is included as a part of Aramis. During testing, the software registers the change in distance between the points, i.e. the change in length of measuring lines and by comparing it to the initial value, calculates strain. In this paper strains have been measured in a welded joint, on the local level. Mechanical properties are determined using stiffness of a specific zone. The stiffness was calculated using the tangent of angle between lines and the horizontal axis in the stressstrain diagram. 


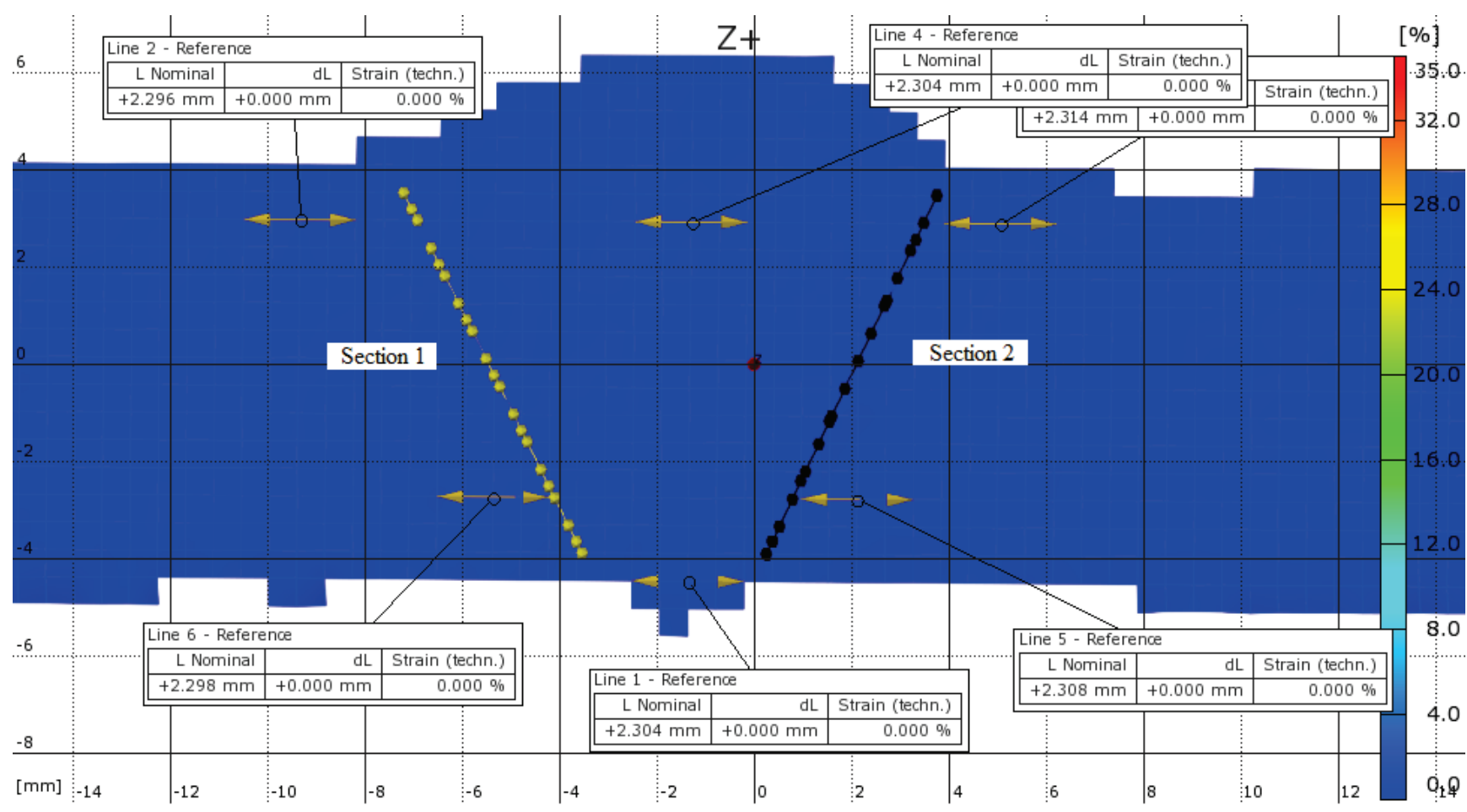

Figure 3 Positions of measuring lines and sections

\section{Results and discussion}

Strain value shown on local level is actually the technical strain and does not depend on the referent grid size.

Fig. 4 shows the stress-strain diagram for the specimen obtained directly from the tensile testing machine. It can be seen from the diagram that the yield point in this case is approximately at $260 \mathrm{MPa}$, for a strain value of approximately $0,67 \%$. It can also be seen that the maximum stress is $390 \mathrm{MPa}$ and that maximum strain is around $29 \%$. The local technical stress was obtained analytically, by dividing the tensile force with the initial area of the specimen cross-section.

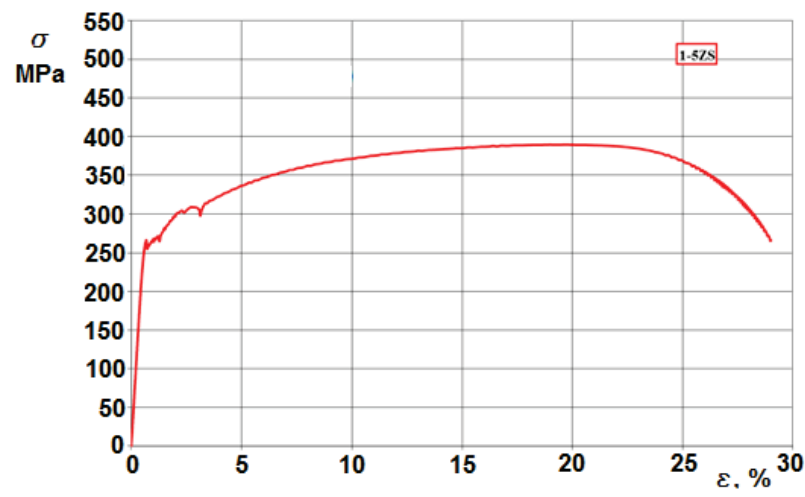

Figure 4 Stress-strain diagram for the specimen

For this diagram (Fig. 4), it was assumed that the stress distribution is uniform in the elastic area for all crosssections of the specimen and thereby for all local zones. In order to obtain an image about the specimen as a whole, values from the diagram obtained from the tensile testing machines (Fig. 4) were compared to the values obtained by DIC (Fig. 5). In this way, it was also possible to gain insight into the mutual influence of individual zones in the welded joint. Yield stress value of the whole specimen was used as maximum value during the calculation of stiffness of the selected local zones.

Misses strain field at yield point is shown in Fig. 5, for the specimen as a whole.

It can be seen from Fig. 5 that the highest strain has occurred in the base material area and in the root side of HAZ and that their values are $0,6 \div 0,7 \%$, which complies with the strain values obtained from the tensile testing machine at yield limit $(0,67 \%)$, (line 6). It should be mentioned that extreme values in Fig. 5, denoted by red colour, represent measuring errors and have not been taken into account during further analysis.

It is also necessary to mention that fracture occurred in the base material adjacent to line 7 . From Fig. 5, it can be seen that there is a peak in strain value in the location where the fracture would occur, and that it appears as soon as yielding starts. Thus, using the non-contact DIC method when the specimen has reached its elasticity limit, allowed the determining of the zone where fracture will occur.

The linear approximations of stress-strain curves in HAZ for root weld and face are shown in Figs. 6 and 7, respectively.

As seen in Fig. 6, the heat affected zones on different sides of the WM in its root part (line 5 and 6 in Fig. 5) have similar stiffness.

Difference in stiffness of these zones is $3 \%$. This difference was calculated by comparing the tangents of angles of lines 5 and 6 , on the stress-strain diagram (Fig. $6)$.

Fig. 7 shows the linear approximation of elastic strain of HAZ in the weld face. By comparing the values of curve slopes in the weld face zone (Fig. 7) with values in weld root zone (Fig. 6), a difference of $15 \%$ was obtained. In addition, it was noticed that the weld face deforms more than the weld root, which lead to pressure in the root part of the HAZ (Fig. 6). Multiple factors can cause such specimen behaviour. Some of them include different degree of mixing in the face and the root, the shape of the weld (in 
this case V), residual stresses and increased mass of added material on the weld face side. Based on the results shown in Figs. 6, 7 and 8, it can be clearly seen that the stiffness of the weld face is lower than that of the root, observed on the local level.

Fig. 8 shows the slopes of all selected zones, enabling comparison of their mechanical properties.

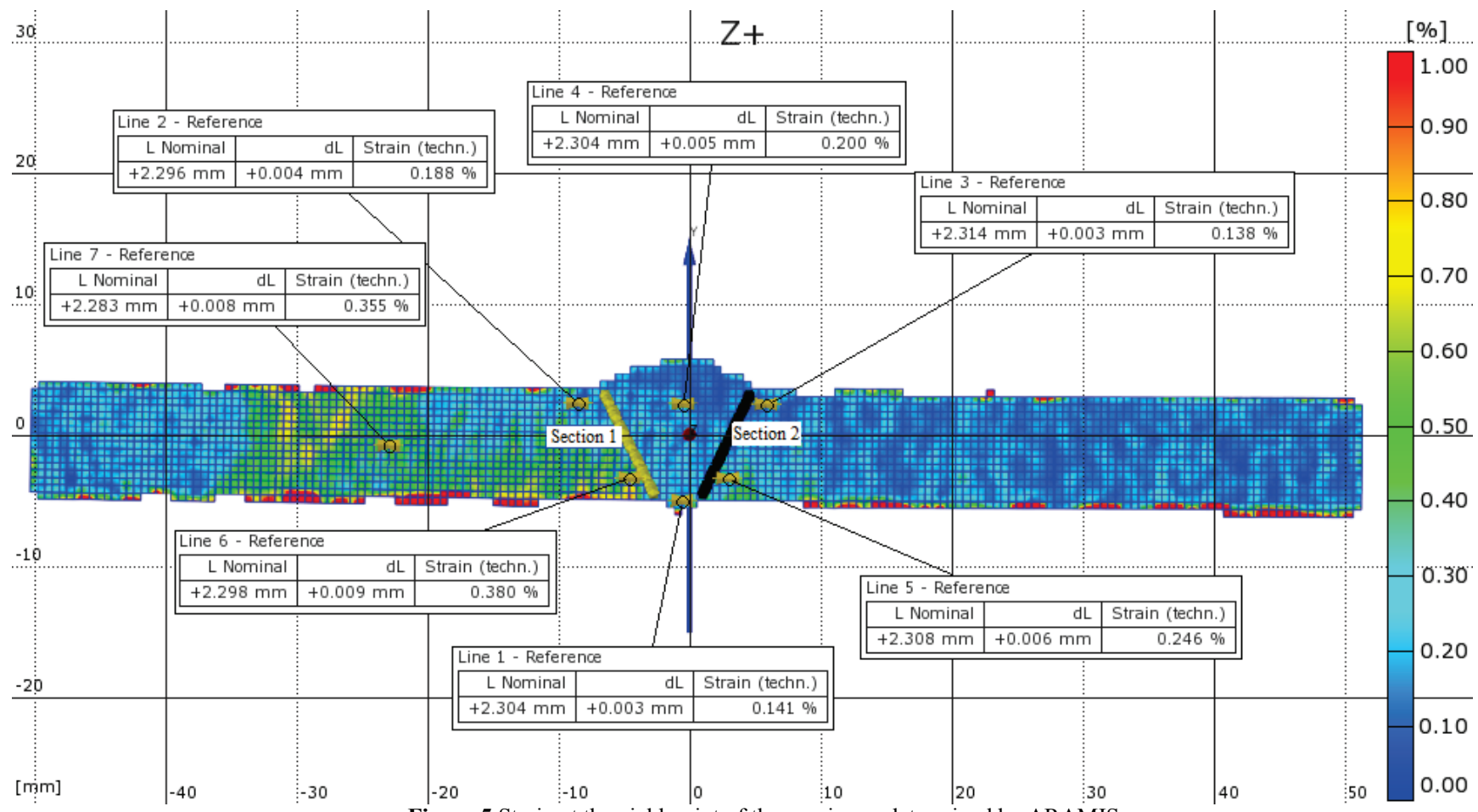

Figure 5 Strain at the yield point of the specimen, determined by ARAMIS

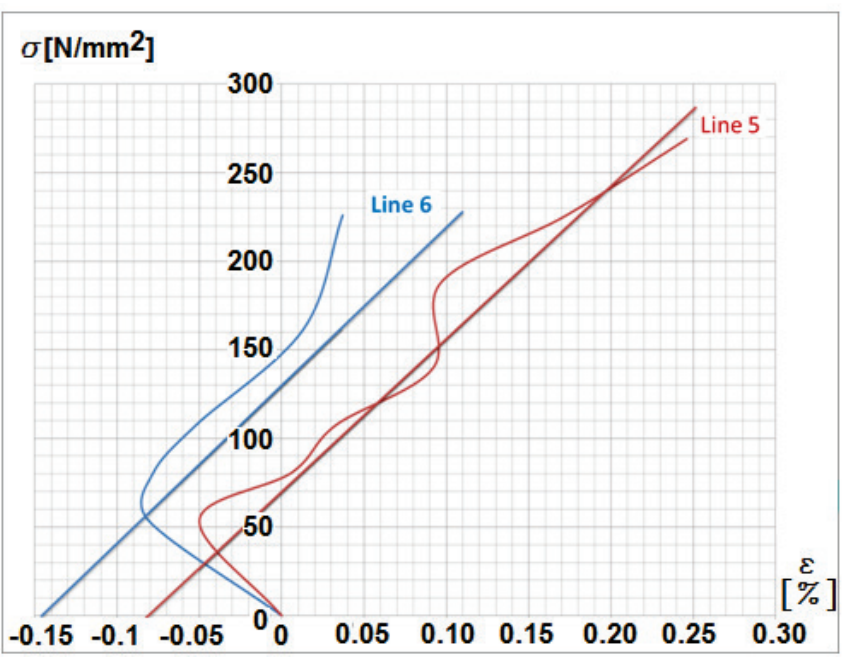

Figure 6 Elastic strain in HAZ in the weld root

Table 1 Test results - stiffness $(\mathrm{GPa})$

\begin{tabular}{|c|c|c|c|c|c|}
\hline \multicolumn{5}{|c|}{ Test results - stiffness $S(\mathrm{GPa})$} \\
\hline \multicolumn{2}{|c|}{ WM } & \multicolumn{5}{c|}{ HAZ } \\
\hline Line 1 & Line 4 & Line 6 & Line 5 & Line 2 & Line 3 \\
\hline 176 & 77,6 & 122,2 & 87 & 135 & 156 \\
\hline
\end{tabular}

It can be seen from Tab. 1 that the weld root has the highest stiffness (line 1), which is around 2,3 times higher than the stiffness of the weld face (line 4). Based on the shown measuring and stiffness calculations, it was confirmed that the first hypothesis is correct, i.e. that in case of tension in a $\mathrm{V}$-weld specimen (Base material S235JRG2, electrode wire - VAC 60), there is a mutual

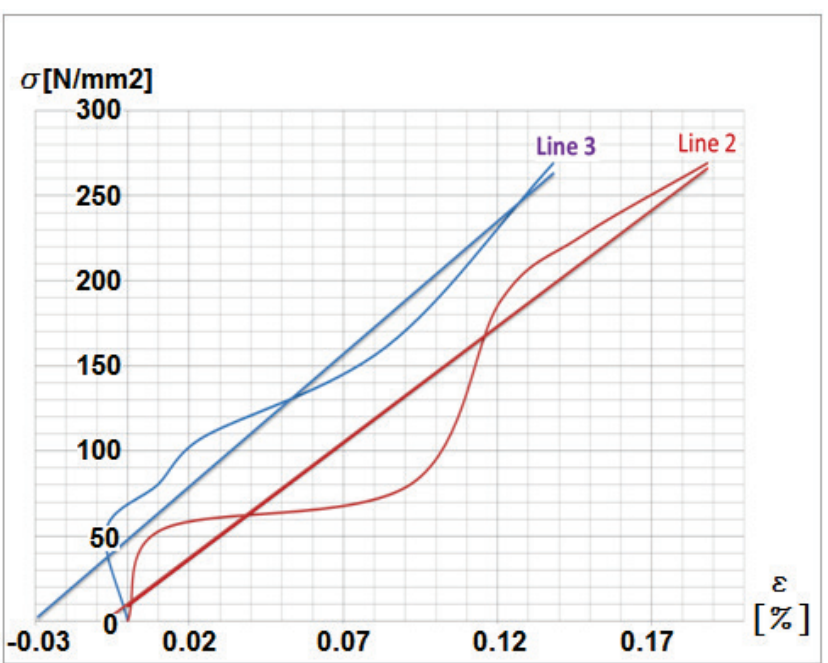

Figure 7 Elastic strain in HAZ in the weld face

influence of mechanical properties of local zones, wherein the weld root has the highest stiffness.

In this paper, stress was calculated as the ratio between the applied force and the area of the characteristic cross-section. Cross-section area was taken as a constant for a characteristic local cross-section. Epsilon represents the ratio between the initial and current length of a small local line.

According to standard tests, $\varepsilon$ is calculated for total specimen length, whereas in this paper the local value of $\varepsilon$ was measured for a characteristic line. In addition, a linear approximation of the curve was performed, for the purpose of obtaining its slope, i.e. the $\sigma-\varepsilon$ diagram. Straight lines (Fig. 8) were not approximated from zero, 
therefore the slope is smaller (as according to standards). Slopes of the root (Line 1) and HAZ of the root (Line 5, 6) start from a negative value due to geometry, i.e. the occurrence of specimen bending caused by the pressure in the root part, which was taken into account. During the calculation of $\varepsilon$ according to standards, local occurrence of pressure was not possible to record, since $\varepsilon$ is calculated on a global level.

Various stiffness values shown (Tab. 1) in this paper were not obtained by standard testing, hence obtained stiffness can be observed as local, comparable material property for a given specimen in different zones of a welded specimen.

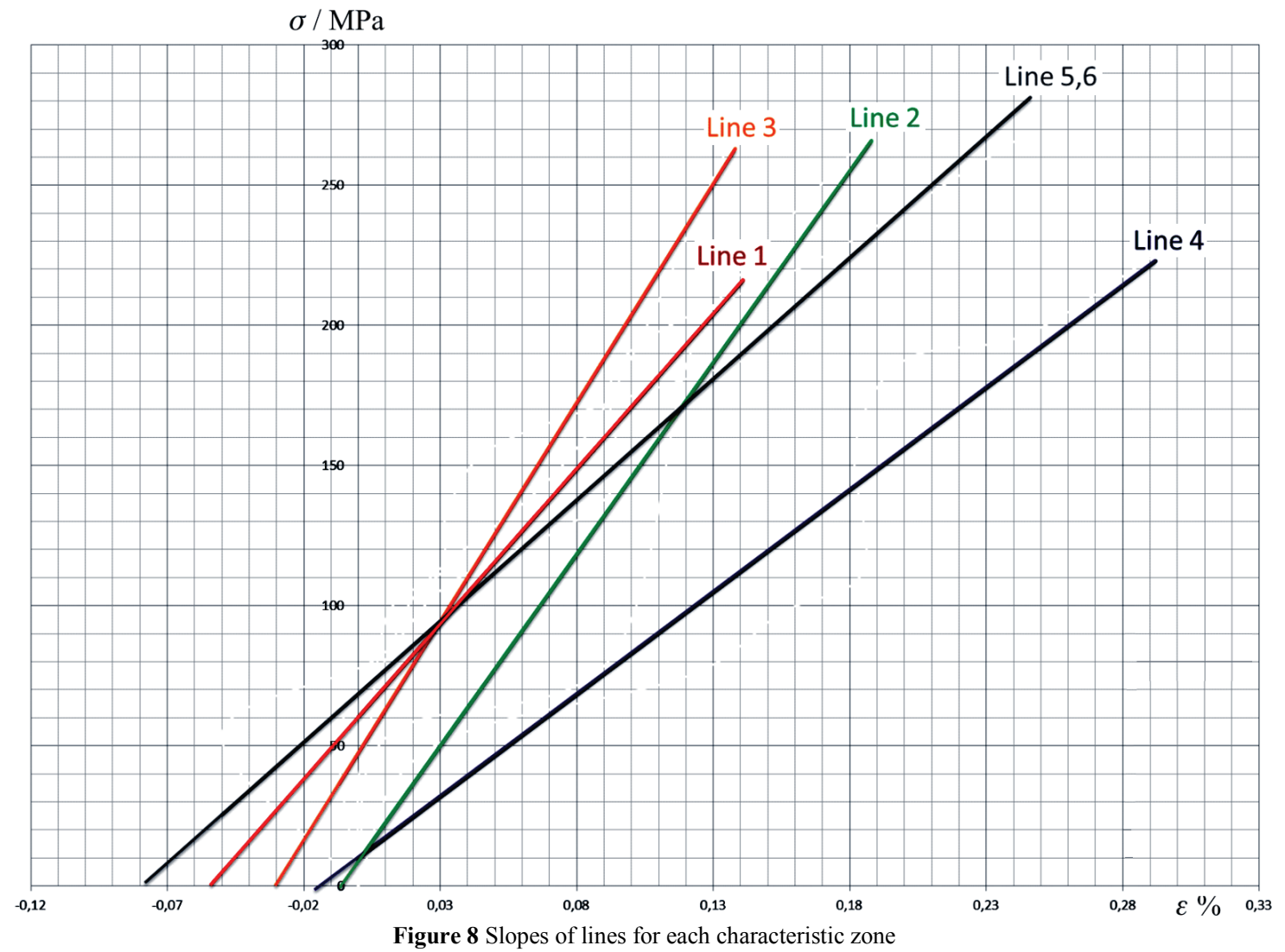

In addition, the zone of local strain with values around $0,7 \%$ (near line 7 ) is shown in Fig. 5, which indicates the location where complete specimen fracture will occur, and these indications appear as soon as the elasticity limit of the specimen is reached. At the end of testing, this is exactly what happened.

\section{Conclusion}

In this study, a methodology for optical non-contact $3 \mathrm{D}$ analysis of local strain in a welded joint subjected to tensile testing was developed. Based on experimental results, stiffness (curve slope) was calculated, for each characteristic local zone. During the tensile testing of a Vweld specimen with an overshoot, the weld face deformed more than the root in the initial stage, which resulted in pressure occurring in the root part of the weld.

Due to tension in the $\mathrm{V}$-weld specimen (Base material - S235JRG2, electrode wire - VAC 60), mutual influence of mechanical properties of local zones is present, wherein the root weld had the highest stiffness.

\section{Acknowledgements}

This research is sponsored and supported by Research grant TR35040 from the Ministry of Education, Science and Technological Development, Republic of Serbia and NATO's Emerging Security Challenges Division in the framework of the Science for Peace and Security Programme.

\section{References}

[1] Tanasic, I.; Tihacek-Sojic, Lj.; Milic Lemic, A.; Djuric, M.; Mitrovic, N.; Milosevic, M.; Sedmak, A. Optical aspect of deformities analysis in the bone-denture complex. // Collegium Antropologicum. 36, (2012), pp. 173-178.

[2] Milosevic, M.; Miletic, V.; Mitrovic, N.; Manojlovic, D.; Savic-Stankovic, T.; Maneski, T. Measurement of local deformation fields in dental composites using 3D optical system. // Chemicke Listy. 105, (2011), pp. 751-753.

[3] Jovicic, R.; Sedmak, A.; Colic, K.; Milosevic, M.; Mitrovic, $\mathrm{N}$. Evaluation of the local tensile properties of austeniteferrite welded joint. // Chemicke Listy. 105, (2001), pp. 754-757.

[4] Miletic, V.; Manojlovic, D.; Milosevic, M.; Mitrovic, N.; Savic Stankovic, T.; Maneski, T. Analysis of local shrinkage patterns of self-adhering and flowable composites using 3D digital image correlation. // Quintessence Int. 42, 9(2011), pp. 797-804

[5] Tihacek Sojic, Lj.; Milic Lemic, A.; Tanasic, I.; Mitrovic, N.; Milosevic, M.; Petrovic, A. Compressive strains and displacement in a partially dentate lower jaw rehabilitated with two different treatment modalities. // Gerodontology. 
29, 2(2012), pp. e851-e857. DOI: 10.1111/j.17412358.2011.00572.x

[6] Milosevic, M.; Mitrovic, N.; Jovicic, R.; Sedmak, A.; Maneski, T.; Petrovic, A.; Aburuga, T. Measurement of local tensile properties of welded joint using Digital Image Correlation method. // Chemicke Listy. 106, (2012), pp. 485-488.

[7] Mitrovic, N.; Milosevic, M.; Momcilovic, N.; Petrovic, A.; Sedmak, A.; Maneski, T.; Zrilic, M. Experimental and numerical analysis of local mechanical properties of globe valve housing. // Chemicke Listy. 106, (2012), pp. 491-494.

[8] Sedmak, A.; Milosevic, M.; Mitrovic, N.; Petrovic, A.; Maneski, T. Digital image correlation in experimental mechanical analysis. Integritet $\mathrm{i}$ vek konstrukcija (Structural Integrity and Life). 12, 1(2012), pp. 39-42.

[9] Tanasic, I.; Tihacek-Sojic, Lj.; Milic-Lemic, A.; Mitrovic, N.; Mitrovic, R.; Milosevic, M.; Maneski, T. Analysing Displacement in the Posterior Mandible using Digital Image Correlation Method. // J Biochip Tissue chip S1:006, 2011.

[10] Tanasic, I.; Tihacek-Sojic, Lj.; Milic Lemic, A.; Mitrovic, N.; Milosevic, M.; Mitrovic, R.; Maneski, T. Strain Behavior in the Restored Edentulous Mandible Bone. // J Bioengineer \& Biomedical Sci 2:107, 2011.

[11] Mitrovic, N.; Milosevic, M.; Sedmak, A.; Petrovic, A.; Prokic-Cvetkovic, R. Application and Mode of Operation of Non-Contact Stereometric Measuring System of Biomaterials. // FME Transactions. 39, 2(2011), pp. 55-60.

[12] Lemmen, H. J. K.; Alderliesten, R. C.; Benedictus, R.; Hofstede, J. C. J.; Rodi, R. The power of Digital Image Correlation for detailed elastic-plastic strain measurements. // WSEAS International Conference on Engineering Mechanics, Structures, Engineering Geology (EMESEG '08), Heraklion, Greece (2008), pp. 73-89.

[13] Hung, P.-C.; Voloshin, A. S. In-plane Strain Measurement by Digital Image Correlation. // J. of the Braz. Soc. of Mech. Sci. \& Eng. XXV, 3(2003), pp. 215-221. DOl: 10.1590/s1678-58782003000300001

[14] Gurpreet, Kaur. Experimental and numerical analysis of tensile test, Mechanical Engineering Department. Thapar Institute of Eng. And Technology, Patiala (Punjab). http://dspace.thapar.edu:8080/dspace/bitstream/123456789/ 317/1/8048126.pdf

[15] Mishra, R. S.; Ma, Z. Y. Friction stir welding and processing. // Materials Science and Engineering. 50, 12(2005), pp. 1-78. DOI: 10.1016/j.mser.2005.07.001

[16] Hector, L. G.; Chen, Y.-L.; Agarwal, S.; Briant, C. L. Friction stir processed AA5182-O and AA6111-T4 aluminum alloys. Part 1: electron backscattered diffraction analysis. // Journal of Materials Engineering and Performance. 16, 4(2007), pp. 391-403. DOl: 10.1007/s11665-007-9060-0

[17] Genevois, C.; Deschamps, A.; Vacher, P. Comparative study on local and global mechanical properties of 2024 T351, 2024 T6 and $5251 \mathrm{O}$ friction stir welds. // Materials Science and Engineering. A 415, (2006), pp. 162-170. DOI: 10.1016/j.msea.2005.09.032

[18] BS EN 2243-6:2005, Aerospace series - Non-metallic materials - Structural adhesives - Test method - Part 6: Determination of shear stress and shear strain, Report.

[19] Vlot, A.; Gunnink, J. W. Fibre Metal Laminates an Introduction, Kluwer Academic Publishers, (2001). DOI: 10.1007/978-94-010-0995-9

[20] Reynolds, A. P.; Duvall, F. Digital Image Correlation for Determination of Weld and Base Metal Constitutive behavior, Department of Mechanical Engineering, University of South Carolina, Columbia, (1999).

[21] Chu, T. C.; Ranson, W. F.; Sutton, M. A.; Peters, W. H. Application of digital-image-correlation techniques to experimental mechanics. // Experimental Mechanics. 25, 3(1985), pp. 232-244. DOI: 10.1007/BF02325092

[22] Vellinga, W. P.; Onraet, S. Measurement of Strain Fields in the Micron Range. // Proceedings of the joint Meeting of the BVM and the NVvM 2000 in Papendal, (2000).

[23] Masakazu, Shibahara; Shota, Tsuboi; Shinsuke, Itoh; Toichi, Fukasawa. Time-history Measurement of Welding Deformation Using Digital Image Correlation Technique, Osaka Prefecture University Sakai, Osaka, Japan, (2011).

[24] Hild, F.; Roux, S. Digital image correlation: from displacement measurement to identification of elastic properties - a review, (2006).

[25] Kirugulige, M. S.; Tippur, H. V.; Denney, T. S. Measurement of transient deformations using digital image correlation method and high-speed photography: application to dynamic fracture. // Applied Optics. 46, 22(2007), pp. 5083-5096. DOI: 10.1364/AO.46.005083

\section{Authors' addresses}

\section{Dr. Miloš Milošević}

University of Belgrade,

Innovation Center of Faculty of Mechanical Engineering, Kraljice Marije 16, 11000 Belgrade, Serbia

E-mail: mmilosevic@mas.bg.ac.rs

\section{Nenad Milošević}

University of Belgrade, Faculty of Mechanical Engineering, Kraljice Marije 16, 11000 Belgrade, Serbia E-mail: nenad.milosevic28608@gmail.com

\section{Simon Sedmak}

University of Belgrade,

Innovation Center of Faculty of Mechanical Engineering, Kraljice Marije 16, 11000 Belgrade, Serbia E-mail: simon.sedmak@yahoo.com

\section{Uroš Tatić}

University of Belgrade, Innovation Center of Faculty of Mechanical Engineering

Kraljice Marije 16, 11000 Belgrade, Serbia

E-mail: taticuros@gmail.com

\section{Nenad Mitrović}

University of Belgrade, Faculty of Mechanical Engineering, Kraljice Marije 16, 11000 Belgrade, Serbia

E-mail: nmitrovic@mas.bg.ac.rs

\section{Dr. Sergej Hloch}

Institute of Geonics Academy of Sciences of the Czech Republic, Ostrava Poruba,

Studentska 1768, 70800 Ostrava-Poruba, Czech Republic E-mail: sergej.hloch@tuke.sk

\section{Radomir Jovičic}

University of Belgrade,

Innovation Center of Faculty of Mechanical Engineering, Kraljice Marije 16, 11000 Belgrade, Serbia

E-mail: rjovicic@mas.bg.ac.rs 